\title{
Identification of Potential Groundwater Recharge Zones Using Remote Sensing and Geographical Information System in Amaravathy Basin
}

\author{
Raviraj A*, Nimmi Kuruppath and Balaji Kannan
}

Agricultural College and Research Institute, Tamil Nadu Agricultural University, Coimbatore, Tamil Nadu, India

\begin{abstract}
Integration of remote sensing and geographical information system (GIS) has become a breakthrough in the field of groundwater studies. The demand for water is increasing exponentially each year showing an increase in dependence on groundwater sources as surface water sources are no longer satisfying the demand. The present study attempts to identify the potential recharge zones and locations for artificial recharge structures in Amaravathy Basin, Tamil Nadu. Weighted overlay analysis tool in Arc GIS application is used to identify the areas. The input data for this analysis are different layers like geology, geomorphology, soil, rainfall, land use-land cover, soil lineament density and drainage density. The result depicted the groundwater potential zones into four categories, viz., good, moderate, low and poor that and can be used for better planning and management of groundwater resources. Various groundwater recharge structures like boulder dams, check dams, percolation tanks, recharge pits etc., were suggested in appropriate locations of Amaravathy basin according to the derived results.
\end{abstract}

Keywords: Identification of recharge zones; Remote sensing; GIS; Amaravathy basin

\section{Introduction}

Groundwater is the largest available source of fresh water lying beneath the ground and constitutes an important source for various purposes like domestic needs, supply for industries and for agriculture etc. Moreover, due to over exploitation the availability of groundwater is reducing steeply. Besides targeting groundwater potential zones, it has now become crucial to target recharge zones for artificial recharge in order to safe guard the future.

Artificial recharging structures are one of the effective techniques for the management of groundwater resources. Since the eighteenth century onwards, groundwater storage structures like ponds, canals, and reservoirs have been used to store surface water all over India, but it is neither fully scientific nor geographic location based. In order to circumvent these issues in identifying the groundwater recharge zones, the recent geospatial technologies like Remote Sensing and Geographical Information System could be used with relatively accurate results. Remote sensing with its advantages of spatial, spectral and temporal availability of data covering large and inaccessible areas within short time has become a very handy tool in assessing, monitoring and conserving groundwater resources. It is also possible to demarcate the highpotential sites for artificial recharge in both accessible and inaccessible areas. The specific details of water resource systems including drainage density, stream order and their associated geographical features should be incorporated to get credible conclusions for the relative benefits and alternative management policies. Identification of potential sites for artificial recharge is governed by several factors such as geology, geomorphology, lineaments, landuse/cover, drainage density, soil texture and slope.

Amaravathy river is one among the main tributaries of the river Cauvery and is surrounded by four districts viz., Coimbatore, Dindigul, Karur and Tirupur in Tamil Nadu. In Karur district 9 out of 15 blocks is over-exploited, 5 is semi-critical and one is under critical category. Coimbatore district has 6 blocks under over exploited category of the 12 blocks, 4 under semi-critical and 2 under safe category. While in Dindigul district out of the 14 blocks 11 is under exploited 2 is semi-critical and only one block is under safe category. Tirupur district is having 2 blocks under over-exploited category, 1 under critical and 7 and 3 numbers of blocks under semi-critical and safe categories respectively. (CGWB). The flow in the river is seasonal and is contributed by the northeast and southwest monsoon seasons. The surface flow in the rivers can be observed only during monsoon periods. The deficient monsoon rainfall has affected the flow of surface water into reservoirs, lakes etc. Hence under these circumstances the farmer has to totally depend on alternate source, viz. groundwater to meet-out their irrigation requirements and hence the groundwater resource in Amaravathy basin is declining. As per CGWB out of the 31 blocks covering Amaravathy basin 16 blocks are identified to be under over-exploited category, 5 under critical, 2 under semi critical and 8 under safe category. Therefore, based on existing groundwater development condition the basin is categorized under over-exploited area and identification of potential recharge zones is necessary to improve the groundwater scenario of the basin.

\section{Details of the Study Area}

The study area, Amaravathy basin is one among the main tributaries of the river Cauvery in its mid reach. The total area of the basin (4B2A6) is 8440 sq.km (PWDWRO). It lies between the latitude $10^{\circ} 06^{\prime} 51^{\prime \prime} \mathrm{N}$ and $11^{\circ} 02^{\prime} 10^{\prime \prime} \mathrm{N}$ and longitude $77^{\circ} 03^{\prime} 24^{\prime \prime} \mathrm{E}$ and $78^{\circ} 13^{\prime} 06^{\prime \prime} \mathrm{E}$ surrounding four districts viz., Coimbatore, Dindigul, Karur and Tirupur in Tamil Nadu. The basin is covered by survey of India top sheets $58 \mathrm{~F} 1,2,3,4,5,6,7$, $8,9,10,12,13,14,15,16,58 \mathrm{~J} 1,2,11,13$ and is bounded by the Vaigai basin on the south, Noyyal basin on the north, Parambikulam and Aliyar basin on the west and Ayyalur basin and Kadavur hills on the east.

*Corresponding author: Raviraj A, Agricultural College and Research Institute, Tamil Nadu Agricultural University, Coimbatore, Tamil Nadu, India, Tel: 04226611213; E-mail: ravitnau@gmail.com

Received September 09, 2017; Accepted October 25, 2017; Published October 27, 2017

Citation: Raviraj A, Kuruppath N, Kannan B (2017) Identification of Potential Groundwater Recharge Zones Using Remote Sensing and Geographical Information System in Amaravathy Basin. J Remote Sensing \& GIS 6: 213. doi: 10.4172/2469-4134.1000213

Copyright: @ 2017 Raviraj A, et al. This is an open-access article distributed unde the terms of the Creative Commons Attribution License, which permits unrestricted use, distribution, and reproduction in any medium, provided the original author and source are credited. 
Citation: Raviraj A, Kuruppath N, Kannan B (2017) Identification of Potential Groundwater Recharge Zones Using Remote Sensing and Geographical Information System in Amaravathy Basin. J Remote Sensing \& GIS 6: 213. doi: 10.4172/2469-4134.1000213

Page 2 of 10

Amaravathy river raises from Naimakad at an elevation of $2300 \mathrm{~m}$ above MSL in the Western Ghats (Anaimalai) in Idukki district of Kerala state. The river has five major tributaries viz., Kuthiraiyar, Shanmuganadhi, Nallathangalodai, Nanganjiar and Kodavanar from the south. The tributaries joining on the left are the Upparodai and Vattamalaikkaraiodai.

The basin is more or less fan shaped and has a length of about 188 $\mathrm{km}$ from west to east and an average width of $81 \mathrm{~km}$ from the south to north. One third of the sub basin area is covered with agricultural land and crop land. Amaravathy Basin covers almost 31 blocks of which 16 blocks are identified to be under over-exploited category, 5 critical, 2 semi critical and 8 under safe by CGWB (Central Ground Water Board). Therefore, based on existing groundwater development condition the basin is categorized under over-exploited area and identification of potential recharge zones is necessary to improve the groundwater condition of the basin. The location map of the study area, along with the categorization of blocks is shown in Figure 1.

The tasks can basically be divided in to the following categories:

( Collection of base map and thematic maps of the study area.

( P Processing of data and assigning weightage.

( Identification of potential recharge zones using weighted overlay technique in ArcGIS 10.1.

\section{Climate}

The basin has four distinct seasons, south west monsoon from June to September, north east monsoon from October to December, the winter season from January to February and summer from March to May. The average annual rainfall of the basin is $653 \mathrm{~mm}$ which is smaller than the state average of $941 \mathrm{~mm}$ (Yasodha).

\section{Geology}

Hornblende-biotite gneisses form the major rock type of the basin followed by charnockites and sand. Amaravathy basin may be divided into three physiographic divisions such as undulating plains, plateau and hill region with shallow and texture soil [1]. Recent alluvial deposits of sand and silt found on the flood plain area of Amaravathy near Karur and Udumalpet blocks in the Amaravathy basin.

\section{Lineament}

The lineament map is a measure of quantitative length of linear features expressed in a grid. Lineament density map of an area can indirectly

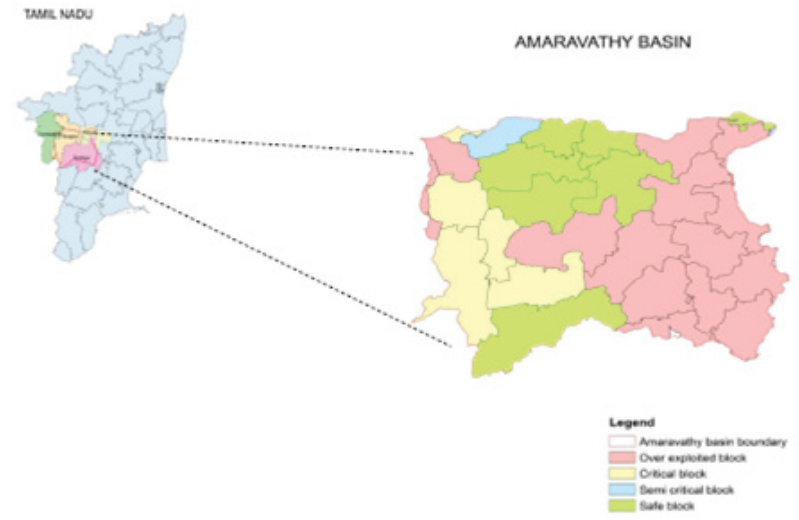

Figure 1: Study area reveal the groundwater recharge zones, since the presence of lineaments usually denotes a permeable zone. Areas with high lineament density are favorable for groundwater development. Highest lineament density is found in the southern side of Amaravathy basin whereas the lowest is recorded as isolated patches of the entire basin. The basins lineament density is classified into two categories viz., present and not present [2].

\section{Drainage density}

Drainage density is an expression of the closeness of spacing channels, thus providing a quantitative measure of length of stream with a square grid of the area in terms of $\mathrm{km} / \mathrm{km}^{2}$. Areas having high density are not suitable for groundwater development because of the greater surface runoff. In general, the Amaravathy river basin drainage pattern is dendritic.

\section{Geomorphology}

The Amaravathy basin area is having more spread of pediplain weathered/ buried, and areas of low relief constituting buried pediments. Pediments with a number of icebergs both in granites and gneisses which cannot be separated and mapped as the individual units are referred to as pediment inselberg complex. According to the recharge capability, geomorphologic units are classified into five classes viz., very good, good, moderate good, moderate poor and poor.

\section{Slope}

The slope of an area is an important parameter which determines the groundwater recharge capability. The slope of Amaravathy basin ranges from 0 to $50 \%$. The majority of the study area is under low degree of slope, this plain to gentle slope area characterized by very good category for groundwater recharge due to nearly flat terrain, and slow surface runoff allowing more time for rain water to percolate. The area with a steep slope is considered as poor groundwater recharge areas due to higher slope, higher runoff, and low infiltration [3].

\section{Land use}

The study area mostly consists of crop land, plantation, current fallow followed by water bodies, built up rural and urban, grassland, scrub land, mining and forest. From the land use point of view, crop lands are an excellent site for groundwater potential. Meanwhile built up land is given a low score due to the affected recharge of the groundwater regime by inhibiting precipitation through the aquifers.

\section{Soils}

The predominant soil types found in this river basin are sand, loam, sandy loam, loamy sand, sandy clay loam, clay loam, sandy clay and clay. Because of this varying soil types, the groundwater recharge capability varies.

\section{Materials and Methods}

\section{Research methodology}

Each of the thematic maps has been reclassified and assigned suitable weightage according to multi influencing factor. Groundwater potential recharge zones were identified by overlaying all the thematic maps in terms of weighted overlay methods using the spatial analysis tool in ArcGIS 10.1.

The multiple parameter analysis for delineating groundwater recharge sites in the study area has been done by Multiple Influencing Factor (MIF) technique. In this study, seven spatial parameters such as geology, geomorphology, slope, land use and land cover, lineament density, 
Citation: Raviraj A, Kuruppath N, Kannan B (2017) Identification of Potential Groundwater Recharge Zones Using Remote Sensing and Geographical Information System in Amaravathy Basin. J Remote Sensing \& GIS 6: 213. doi: 10.4172/2469-4134.1000213

Page 3 of 10

drainage density and soil texture are analyzed by MIF approach. Figure 2 gives the flowchart showing methodology adopted for the present study which was used for fulfilling the objectives of the study.

\section{Data collection}

This study involves mapping of different features that influence groundwater recharge in different degrees. Hence thematic maps of Geomorphology, Geology, LULC, Soil, Slope, and Lineament of the study area were obtained from various sources for analyzing and integrating to get the final result.

Cartosat DEM data on a global scale at $30 \mathrm{~m}$ horizontal resolution are available through the Bhuvan (Gateway to Indian Earth Observation) ISRO's geo-portal (http://bhuvan.nrsc.gov.in/data/download/index. php) and are used for generating thematic layers like drainage.

\section{Preparation of thematic layers and assigning of ranks}

The Cartosat DEM (30 m) data was obtained from Bhuvan (ISRO's geo-portal) and was used to develop drainage density map. Existing data of geology, geomorphology, soil, landuse, and slope were converted from 'shp' format to raster format using polygon to raster tool and a cell size of $30 \mathrm{~m}$ was applied to all the maps during conversion. Then all the maps were projected to WGS 1984 Transverse Mercator. Lineament map was converted to lineament density $\left(\mathrm{km} / \mathrm{km}^{-2}\right)$ map using line density tool of spatial analysis tool. Each parameter is assigned weights from 1 to 4 scales as per the degree of contribution to the central theme [4]. The logic of assigning weightage to each polygon of each theme is given in Table 1 .

\section{Preparation of slope map}

The Cartosat DEM data were used to derive the slope map, which is presented in terms of percentage using the 'slope' function in ArcGIS. It was then converted from .shp to raster format and reclassified into

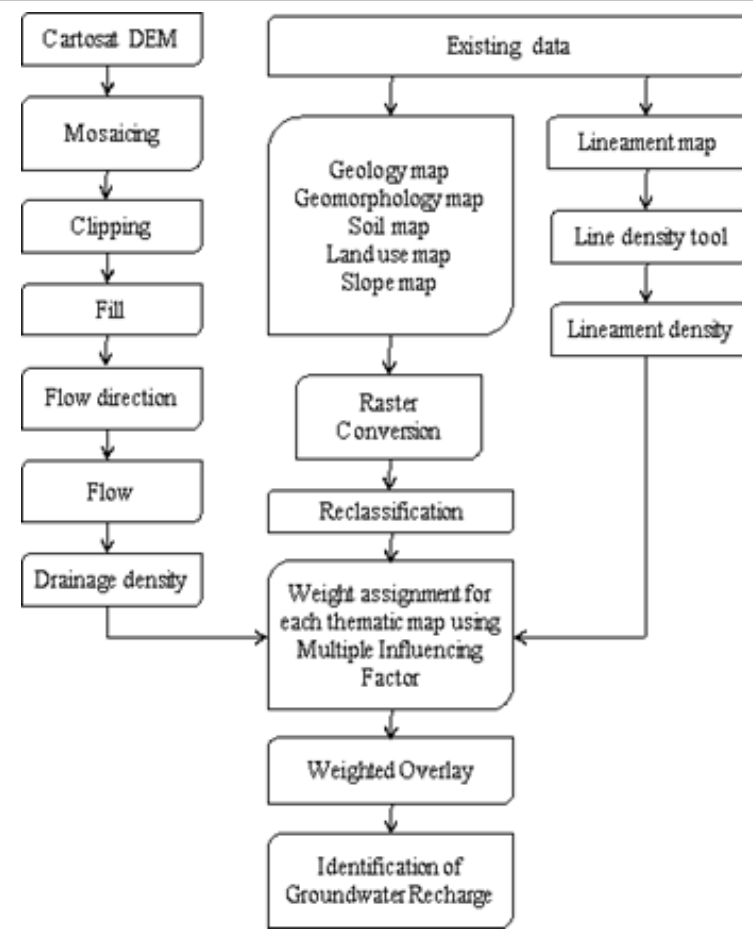

Figure 2: Flow chart showing methodology adopted to identify potential groundwater recharge zones.

\begin{tabular}{|c|c|c|}
\hline S. No & Rank & Logic value \\
\hline & 1 & High contribution to central theme \\
\hline & 2 & Moderate contribution to central theme. \\
\hline & 3 & Low contribution to central theme. \\
\hline & 4 & Least contribution to central theme \\
\hline & \multicolumn{2}{|c|}{ Table 1: Logic of assigning weightage. }
\end{tabular}

different slope classes using re-classify option in the spatial analyst tool. Ranks were assigned for each class of the slope map.

\section{Preparation of soil map}

Soil map of shape file format were converted to raster format using polygon to raster conversion tool. The eight major soil groups found in the study area was then reclassified in order to assign ranks to each class.

\section{Preparation of geomorphology map}

Geomorphological map incorporates relationship of geomorphic units with their groundwater potential as interpreted from the landform characteristics as well as sub surface geology.

\section{Preparation of geology map}

It is well established fact that geological set-up of an area plays a vital role in the distribution and occurrence of groundwater [5]. Geological classes were reclassified and assigned ranks.

\section{Preparation of landuse map}

Land use map of the study area was available in the Department of Remote Sensing and Geographical Information System (GIS), TNAU, Coimbatore in .shp format and it was converted to raster format and later reclassified using the conversion tool and reclassify tool in ArcGIS 10.1. Different landuse classes were assigned different ranks based on their influence on groundwater recharge potential.

\section{Preparation of lineament density map}

Lineaments are linear or curvilinear structures on the earth surface, which depict the weaker zone of bed rocks and the area is considered as secondary aquifer in hard rock regions. In hard rock terrains, lineaments represent areas and zones of faulting and fracturing resulting in increased secondary porosity and permeability and are good indicators of groundwater [6]. The present study used lineament length density $\left(\mathrm{LD}, \mathrm{L}^{-1}\right)$, which represents the total length of lineaments in a unit area, as:

$$
L D=\sum_{i=1}^{i=n} \frac{L i}{A\left(m^{-1}\right)}
$$

Where, $\mathrm{L} i=1=$ total length of lineaments $(\mathrm{m})$ and $\mathrm{A}=$ area of study area $\left(\mathrm{m}^{2}\right)$.

Lineament map was converted to lineament density using the line density tool in spatial analysis tool. This was then classified into two classes viz., lineament present and not present. Areas with lineament was assigned the maximum rank and without lineament with least.

\section{Preparation of drainage density map}

The Cartosat DEM (30 m) data was obtained from Bhuvan (ISRO's geo-portal) and was mosaic and clipped to the study area. The clipped DEM was then filled, using the fill tool in spatial analysis tool to remove small imperfections in the data. To create a raster of flow direction from each cell to its steepest down slope neighbor flow direction tool was used. A raster of accumulated flow was next created using flow 
Citation: Raviraj A, Kuruppath N, Kannan B (2017) Identification of Potential Groundwater Recharge Zones Using Remote Sensing and Geographical Information System in Amaravathy Basin. J Remote Sensing \& GIS 6: 213. doi: 10.4172/2469-4134.1000213

accumulation tool with flow direction as the input. Drainage map was then generated from Cartosat DEM using the raster calculator tool, which was then converted to vector and further the drainage density $\left(\mathrm{km}^{-2}\right)$ map was obtained by the line density analysis tool.

\section{Criteria weightage assignment}

Weight is used to develop a set of relative weights for a group of factors in a multi-criteria evaluation. The multi influencing factors for groundwater potential zones namely geology, slope, land use/landcover, geomorphology, drainage, soil, and lineament were examined and assigned an appropriate weightage according to the multiple influencing factors (MIF) of that particular feature on the hydrogeological environment of the study area [7]. The effect of each major and minor factor is assigned a weightage of 1.0 and 0.5 respectively. The factors and their resulting weights can be used as input for the Weighted Overlay Analysis in ArcGIS environment for overlaying of thematic maps [4].

\section{Data integration analysis in GIS environment}

The thematic maps were used as input in the weighted overlay analysis, during the analysis, the weights were assigned to the thematic layers in the weighted overlay table and each of the classes was ranked accordingly. After assigning weight, the integration of all layers were carried out applying weighted overlay analysis in a GIS environment (ArcMap 10.1). The output map of the weighted overlay analysis gives the groundwater prospect map of the study area.

\section{Results and Discussion}

\section{Thematic layer preparation}

Thematic layers such as geology, geomorphology, slope, soil, landuse/land cover lineament density and drainage density were reclassified and assigned ranks and weights to integrate them to obtain the map of groundwater recharge zones.

\section{Geology}

The study area is predominant with hornblende-biotite gneiss followed by Charnockite. Granites, sand and silt occupy mostly in small mounds or linear domes in the study area.

All the five geological classes were reclassified based on their groundwater recharge potential into very good, moderate, moderate to poor, poor to nil, poor and mapped as shown in Figure 3. The area distribution of the rock types in the study area (Figure 4) shows that about $73 \%$ of the study area is covered by hornblende-biotite gneiss followed by $21 \%$ charnockite, very less area is covered by sand, silt, granite and granet-sillimanite geniss.

\section{Geomorphology}

Geomorphology of an area is one of the most important features in evaluating the groundwater potential and prospect [8]. The geomorphology of the study area is dominated by unit of pediplain weathered / buried followed by denudational and residual hills.

The distribution of the geomorphic classes with respect to groundwater recharge potential are represented in the Figure 5. The areal distribution of geomorphological classes shows that pediplain weathered/buried which covers an extent of $79 \%$, denudational and residual hills was covering around $18 \%$ each of total study area and reservoir and flood plains was covering minimum area of less than $1 \%$ (Figure 6).

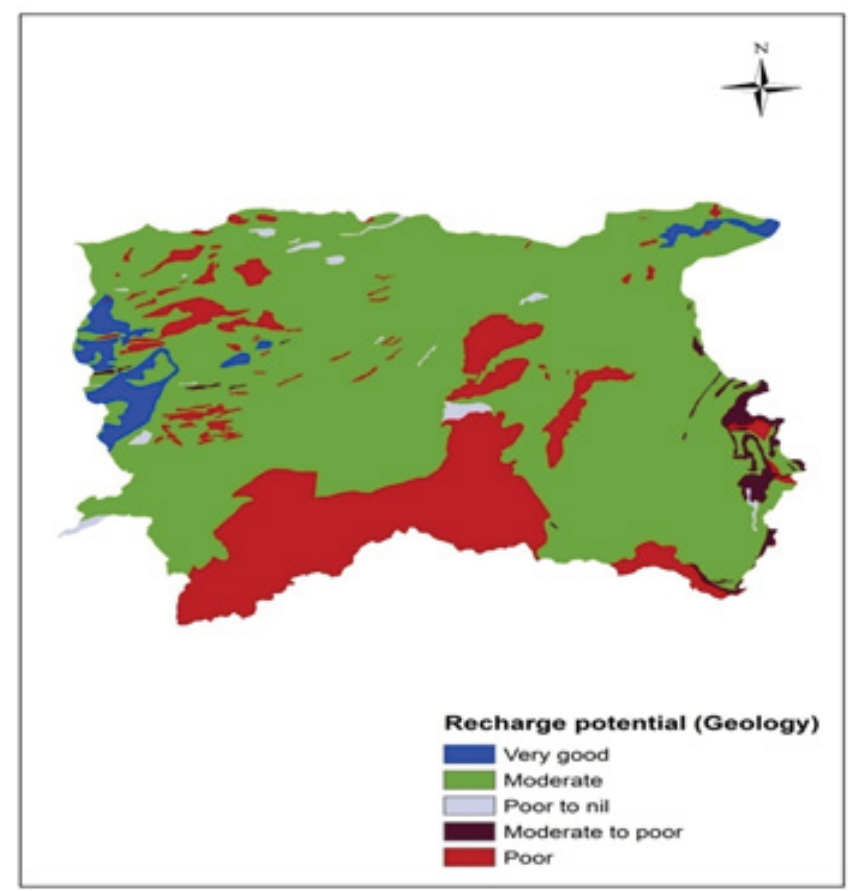

Figure 3: Geology map of Amaravathy basin.

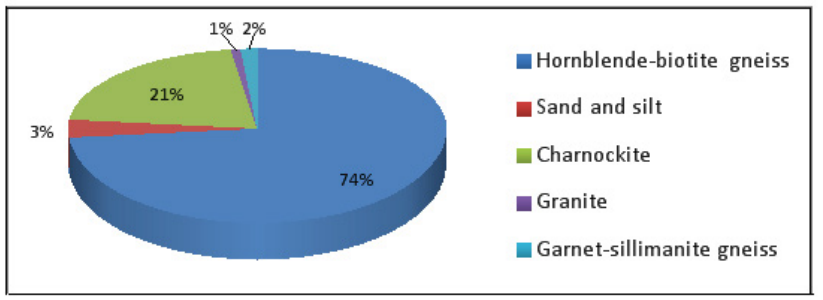

Figure 4: Distribution of rock types in Amaravathy basin.

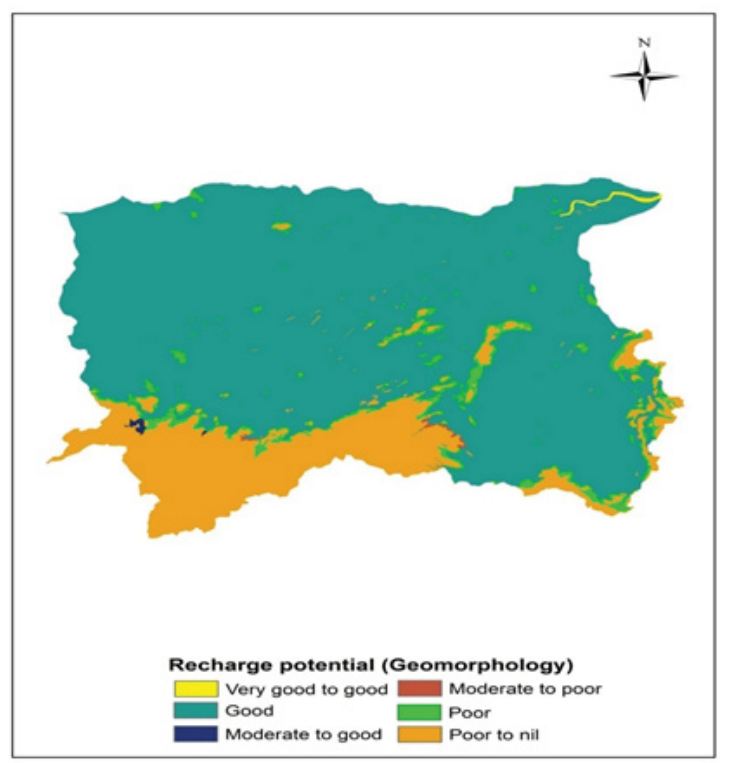

Figure 5: Geomorphology map of Amaravathy basin. 
Citation: Raviraj A, Kuruppath N, Kannan B (2017) Identification of Potential Groundwater Recharge Zones Using Remote Sensing and Geographical Information System in Amaravathy Basin. J Remote Sensing \& GIS 6: 213. doi: 10.4172/2469-4134.1000213

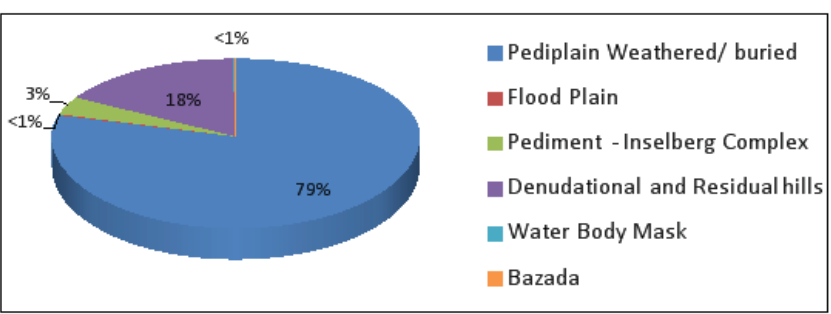

Figure 6: Distribution of Geomorphology in Amaravathy basin

\begin{tabular}{|c|c|}
\hline Hydrological Soil Group & Soil texture classes \\
\hline A & Sand, Sandy loam, Loamy sand, Loam \\
\hline C & Sandy clay loam \\
\hline D & Clay loam, sandy clay, clay \\
\hline
\end{tabular}

Table 2: Hydrologic soil group classification.

\section{Soil}

Based on the hydrologic soil group classification (Table 2), the soil texture classes were categorized and groundwater recharge ability for each class was analyzed. Soil textures clay, clay loam, loamy sand, sandy clay, sandy clay loam and sandy loam were classified into very good, poor and low based on the recharge potential and mapped as shown in Figure 7.

The areal distribution of all the texture classes of soil is shown in Figure 8. Among the soil types found in the study area, sandy loam and sandy clay loam is predominant contributing maximum area of $27 \%$ and $25 \%$ respectively and minimum by sand and loam less than $1 \%$.

\section{Slope}

Slope is one of the factors controlling the infiltration of ground water into subsurface; hence an indicator for the suitability for ground water prospect. In the gentle slope area the surface runoff is slow allowing more time for rain water to percolate, whereas high slope area facilitate high runoff allowing less residence time for rain water hence comparatively less infiltration. The slope percentage in the area varies from 0 to $50 \%$.

The areas having slope of $0-5 \%$ slope falls under 'high' category because of the nearly flat terrain and relatively high infiltration rate. The areas with 5 to $10 \%$ slope are considered as 'moderate' for groundwater recharge due to slightly undulating topography with some runoff. Most of the study area (81\%) falls under 0 to $5 \%$ category. The areas having a slope of 10 to $15 \%$ cause relatively high runoff and low infiltration, and hence are categorized as 'low.' The areas with 15 to $35 \%$ slope (7\%) are considered as 'poor' due to higher slope and runoff. The distribution of slope classes with respect to recharge potential is shown in Figure 9 and the areal distribution of slope classes is presented in pie chart (Figure $10)$.

\section{Land use and land cover}

Land use is an important characteristic of the runoff process that affects infiltration, erosion, and evapotranspiration. The land use pattern of the study area and various land use classes are:

1. Wastelands

2. Agriculture

3. Built-up

4. Water bodies

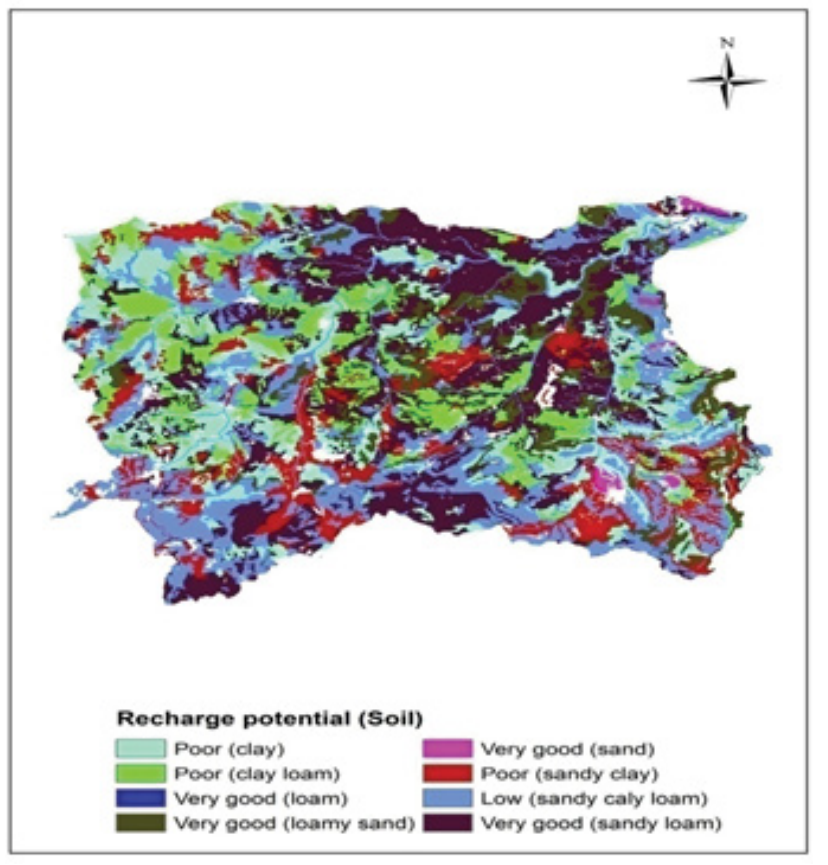

Figure 7: Soil map of Amaravathy basin.

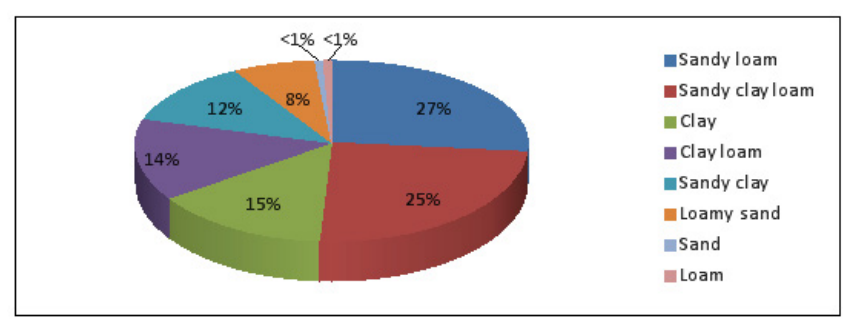

Figure 8: Distribution of soil in Amaravathy basin.

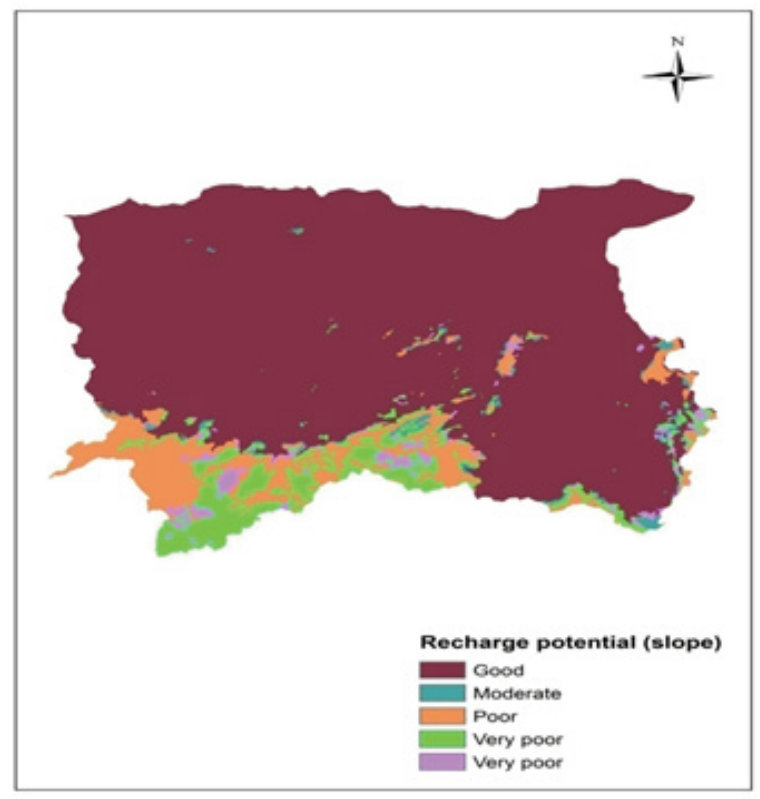

Figure 9: Slope map of Amaravathy basin. 
Citation: Raviraj A, Kuruppath N, Kannan B (2017) Identification of Potential Groundwater Recharge Zones Using Remote Sensing and Geographical Information System in Amaravathy Basin. J Remote Sensing \& GIS 6: 213. doi: 10.4172/2469-4134.1000213

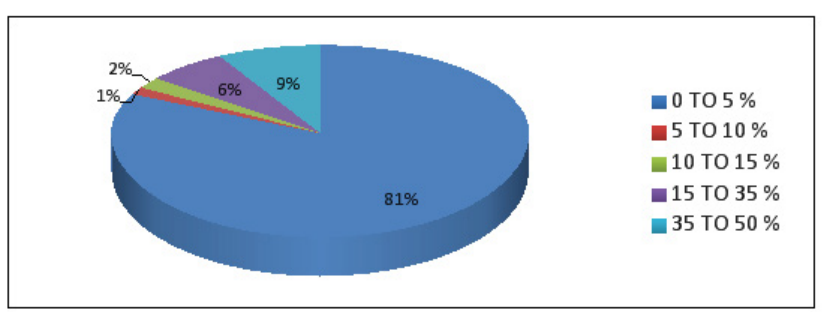

Figure 10: Distribution of Slope in Amaravathy basin.

\section{Forest}

6. Wetlands

The land use map with respect to recharge potential is shown in Figure 11. Land use plays a vital role in groundwater prospecting. The rate of infiltration is directly proportional to the density of vegetation cover, i.e., if the surface is covered by dense forest, the infiltration will be more and the runoff will be less. Water bodies are continuous and excellent source of recharge to ground. Forests, water bodies and crop land were assigned highest rank for groundwater recharge. Barren rocky wastelands and built up area have no groundwater recharge.

Percentage area covered by the particular land use class is depicted in Figure 12. It was observed that agricultural land has maximum area of $77 \%$ followed by forest area which was $12 \%$. Wasteland was about $6 \%$ and minimum area was observed as water bodies, built up lands and wetlands $3 \%, 2 \%$ and less than $1 \%$ respectively.

\section{Lineament density $\left(\mathbf{k m} / \mathbf{k m}^{2}\right)$}

The lineament trends in the study area are predominantly along South-West and North-West. Groundwater potential is high near lineament intersection zones. Lineament density is divided into two classes based on recharge potential; they are very good and poor as shown in Figure 13. Areas with lineament is classified as very good regions for groundwater recharge and given the highest rank and vise versa. The South-West part has very high groundwater recharge potential as the numbers of the lineaments are mostly dominated in this region but the slope is very high therefore it is not preferable for groundwater recharge. The areal distribution of lineament is shown in Figure 14 .

Lineament is present in $69 \%$ of the area, which is categorised under very good class and the rest $31 \%$ of the area does not have lineament.

\section{Drainage density $\left(\mathbf{k m} / \mathbf{k m}^{2}\right)$}

Drainage pattern reflects the major characteristics of the surface as well as subsurface formation. More the drainage density, higher would be the runoff. The suitability of groundwater potential recharge zones is inversely related to drainage density because of its relation with surface runoff and permeability. The drainage density map reveals a density value ranging from 0 to $1.39 \mathrm{~km} / \mathrm{km}^{2}$. For analysis purpose, they were regrouped into four categories viz., $0-0.18,0.18-0.48,0.48-0.68$ and $0.68-1.39 \mathrm{~km} / \mathrm{km}^{2}$. Considering from a recharge point of view, more weightage is assigned to very low drainage density regions, whereas low weightage is assigned to very high drainage density. As per groundwater recharge potential drainage density is classified into four classes viz., very good, good, moderate and poor (Figure 15).

\section{Weightage derivation}

Determination of Weightage of each class is the most crucial in

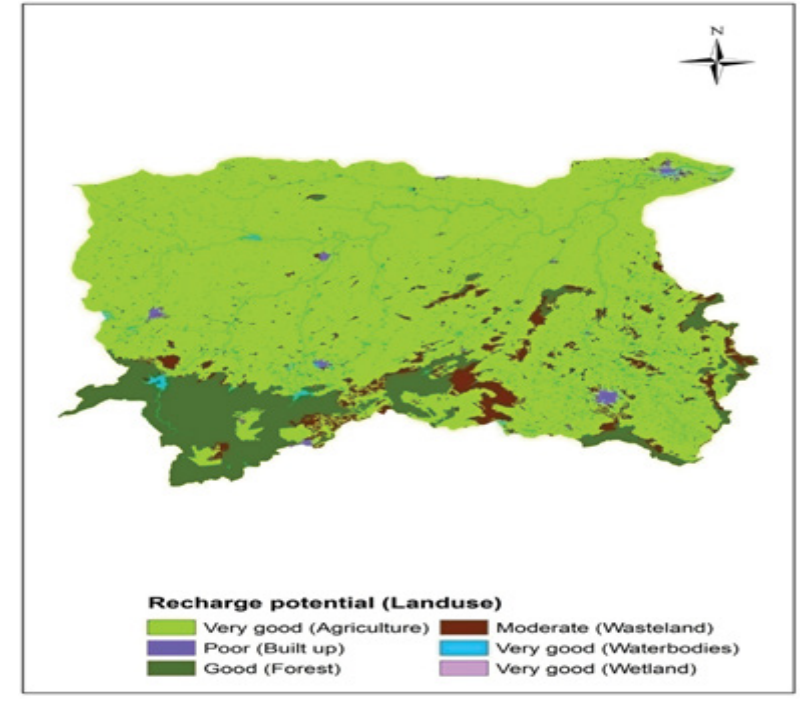

Figure 11: Landuse / land cover map of Amaravathy basin.

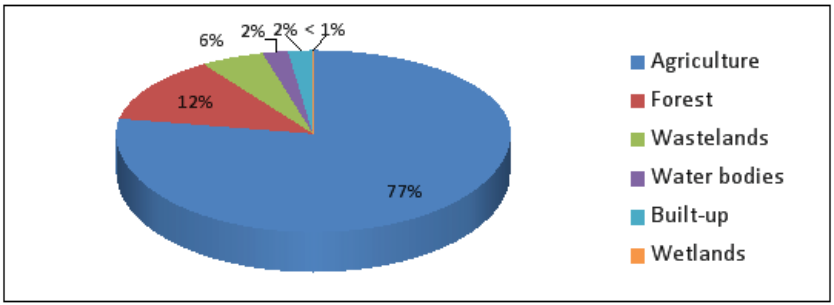

Figure 12: Distribution of Land use Land cover in Amaravathy basin.

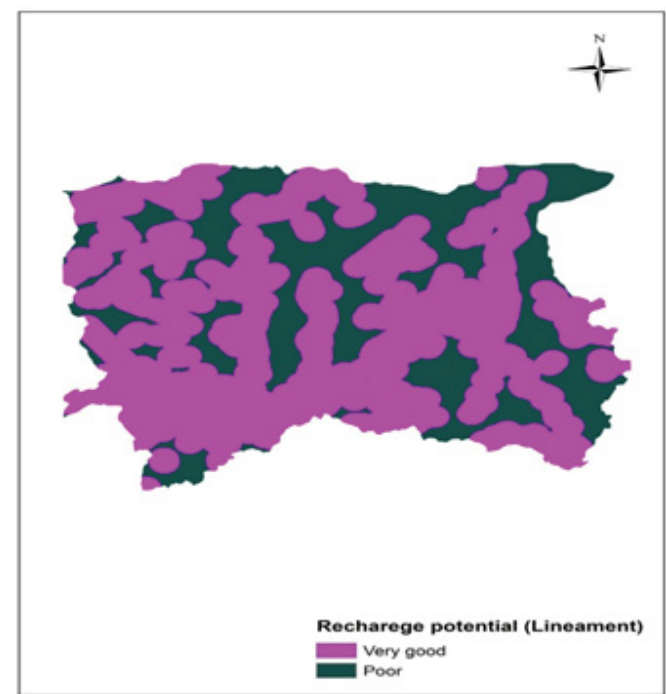

Figure 13: Lineament density map of Amaravathy basin

integrated analysis, as the output is largely dependent on the assignment of appropriate weightage consideration of relative importance leads to a better representation of the actual ground situation [9].

Seven influencing factors, such as geology, slope, land-use/landcover, geomorphology, drainage, soil, and lineament have been identified to delineate the groundwater potential zones. Interrelationship between 
Citation: Raviraj A, Kuruppath N, Kannan B (2017) Identification of Potential Groundwater Recharge Zones Using Remote Sensing and Geographical Information System in Amaravathy Basin. J Remote Sensing \& GIS 6: 213. doi: 10.4172/2469-4134.1000213

Page 7 of 10

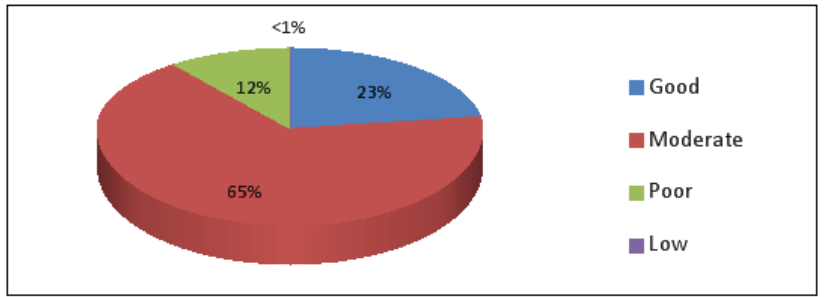

Figure 14: Distribution of Lineament density in Amaravathy basin.

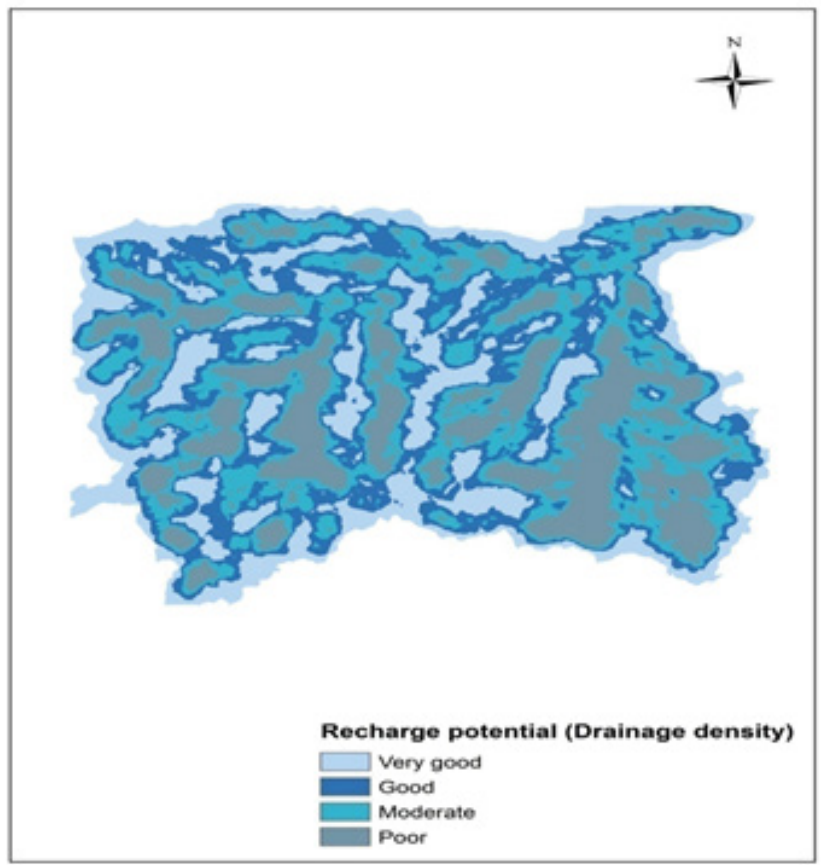

Figure 15: Drainage density map of Amaravathy basin.

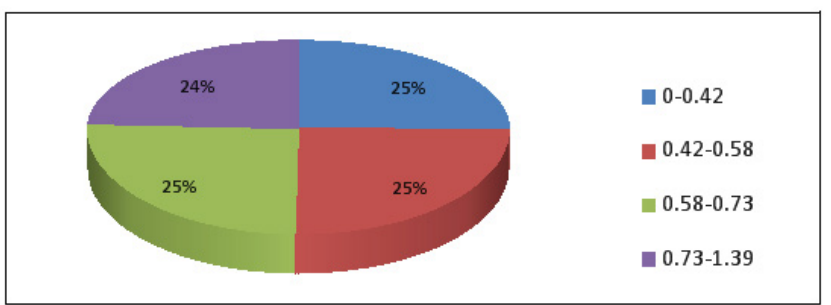

Figure 16: Distribution of Drainage density $\left(\mathrm{km} / \mathrm{km}^{2}\right)$ in Amaravathy basin4.4 Groundwater management strategies.

these factors and their effect is shown in Figure 16. Each relationship is weighted according to its strength. The representative weight of a factor of the potential zone is the sum of all weights from each factor. A factor with a higher weight value shows a larger impact and a factor with a lower weight value shows a smaller impact on groundwater potential zones.

All the thematic maps were reclassified and assigned ranks to each sub class. The weight derivation for each thematic map was done using the Multi Influencing Factor approach and then weighted overlay analysis was done using ArcGIS 10.1 software to delineate ground water recharge zones.

The multi influencing factors for groundwater recharge zones namely geology, slope, land-use/land-cover, geomorphology, drainage, soil, and lineament density were examined and assigned an appropriate weight and are shown in Table 3. The effect of each influencing factor may contribute to delineate the groundwater potential zones. Moreover, these factors are interdependent. The effect of each major and minor factor is assigned a weightage of 1.0 and 0.5 respectively. The cumulative weightage of both major and minor effects are considered for calculating the relative rates. This rate is further used to calculate the score of each influencing factor. The proposed score for each influencing factor is calculated by using the formula:

$$
\left[\frac{A+B}{\sum(A+B)}\right] \times 100
$$

where, A is major interrelationship between two factors and B is minor interrelationship between two factors. Classes of each influencing factors were then assigned ranks with respect to its groundwater recharge potential as shown in Table 4 .

\section{Integration of thematic layers}

After successful derivation of weightage using multiple influencing factors, all the thematic layers were assigned with the derived weightage values and ranks during weighted overlay analysis in ArcGIS 10.1 software to obtain a unified weight map of the potential groundwater recharge areas.

\section{Groundwater recharge zoning map}

Finally, after successful integration of all the thematic maps, an output raster map was obtained. And that map indicates the groundwater recharge zones. Earlier, ranks from 1 to 4 were assigned for individual classes of geology, geomorphology, slope, soil, landuse/ land cover, drainage density and lineament density layers based on the influence on water recharge hence the final output map was also obtained with 4 classes.

As per the rank assignment, value 1 indicates highly controlling units, 2 indicates moderately controlling units, 3 indicates low controlling units and 4 indicates poor controlling reclassified units. Similarly, groundwater recharge areas were delineated and classified as follows: value 1 indicates 'high' or good recharge zones, 2 indicates 'moderate' recharge, 3 indicates 'low' recharge and 4 indicates 'poor' recharge areas (Figure 17).

\begin{tabular}{|c|c|c|c|c|c|}
\hline $\begin{array}{c}\text { S. } \\
\text { No }\end{array}$ & Factor & $\begin{array}{c}\text { Major } \\
\text { effect (A) }\end{array}$ & Minor effect (B) & $\begin{array}{c}\text { Proposed } \\
\text { relative } \\
\text { rates (A+B) }\end{array}$ & $\begin{array}{c}\text { Proposed } \\
\text { score } \\
\text { for each } \\
\text { influencing } \\
\text { factors }\end{array}$ \\
\hline 1 & LULC & $1+1$ & $0.5+0.5+0.5+0.5$ & 4 & 24 \\
\hline 2 & Geology & $1+1+1+1$ & 0 & 4 & 23 \\
\hline 3 & $\begin{array}{c}\text { Lineament } \\
\text { density }\end{array}$ & $1+1$ & 0 & 2 & 12 \\
\hline 4 & Geomorphology & 1 & $0.5+0.5$ & 2 & 11 \\
\hline 5 & Slope & 1 & $0.5+0.5+0.5$ & 2.5 & 15 \\
\hline 6 & $\begin{array}{c}\text { Drainage } \\
\text { density }\end{array}$ & 1 & 0.5 & 1.5 & 9 \\
\hline 7 & Soil & 1 & 0 & 1 & 6 \\
\hline & & & Total & $\sum 17$ & $\sum 100$ \\
\hline
\end{tabular}

Table 3: Effect of factor influencing, relative rates and score for each factor. 
Citation: Raviraj A, Kuruppath N, Kannan B (2017) Identification of Potential Groundwater Recharge Zones Using Remote Sensing and Geographical Information System in Amaravathy Basin. J Remote Sensing \& GIS 6: 213. doi: 10.4172/2469-4134.1000213

Page 8 of 10

\begin{tabular}{|c|c|c|c|c|c|}
\hline S. No & Factors & Classes & Ranking (In words) & $\begin{array}{c}\text { Ranking (In } \\
\text { no.) }\end{array}$ & Weightage (\%) \\
\hline \multirow[t]{6}{*}{1} & Land use Land cover classes & Agriculture & Very good & 1 & 24 \\
\hline & & Wetlands & Very good & 1 & \\
\hline & & Water bodies & Very good & 1 & \\
\hline & & Forest & Good & 2 & \\
\hline & & Wastelands & Low & 3 & \\
\hline & & Built-up & Poor & 4 & \\
\hline \multirow[t]{5}{*}{2} & Geological classes & Sand and silt & Very good & 1 & 23 \\
\hline & & Hornblende-biotite gneiss & Moderate & 2 & \\
\hline & & Garnet-sillimanite gneiss & Moderate-poor & 3 & \\
\hline & & Charnockite & Poor & 4 & \\
\hline & & Granite (Gr1) & Poor-nil & 4 & \\
\hline \multirow[t]{2}{*}{3} & Lineament density Classes $\left(\mathrm{km} / \mathrm{km}^{2}\right)$ & Not present & Poor & 4 & 12 \\
\hline & & Present & Very good & 1 & \\
\hline \multirow[t]{6}{*}{4} & Geomorphologic Classes & Pediplain Weathered/ buried & Good & 1 & 11 \\
\hline & & Flood Plain & Very good -good & 1 & \\
\hline & & Water Body Mask & Moderate-good & 2 & \\
\hline & & Bazada & Moderate-poor & 3 & \\
\hline & & Pediment - Inselberg Complex & Poor & 4 & \\
\hline & & Denudational and Residual hills & Poor-nil & 4 & \\
\hline \multirow[t]{5}{*}{5} & Slope classes (\%) & 0 to $5 \%$ & Good & 1 & 15 \\
\hline & & 5 to $10 \%$ & Moderate & 2 & \\
\hline & & 10 to $15 \%$ & Low & 3 & \\
\hline & & 15 to $35 \%$ & Very poor & 4 & \\
\hline & & 35 to $50 \%$ & Very poor & 4 & \\
\hline \multirow[t]{4}{*}{6} & Drainage density Classes $\left(\mathrm{km} / \mathrm{km}^{2}\right)$ & $0-0.18$ & Very good & 1 & 9 \\
\hline & & $0.18-0.48$ & Good & 1 & \\
\hline & & $0.48-0.68$ & Moderate & 2 & \\
\hline & & $0.68-1.39$ & Poor & 3 & \\
\hline \multirow[t]{8}{*}{7} & Soil classes & Sand (soil group A) & Very good & 1 & 6 \\
\hline & & Sandy loam (Soil group A) & Very good & 1 & \\
\hline & & Loamy sand (Soil group A) & Very good & 1 & \\
\hline & & Loam (Soil group A) & Very good & 1 & \\
\hline & & Sandy clay loam (Soil group C) & Low & 3 & \\
\hline & & Sandy clay (Soil group D) & Poor & 4 & \\
\hline & & Clay loam (Soil group D) & Poor & 4 & \\
\hline & & Clay (Soil group D) & Poor & 4 & \\
\hline
\end{tabular}

Table 4: Weighted factors influencing the recharge zones.

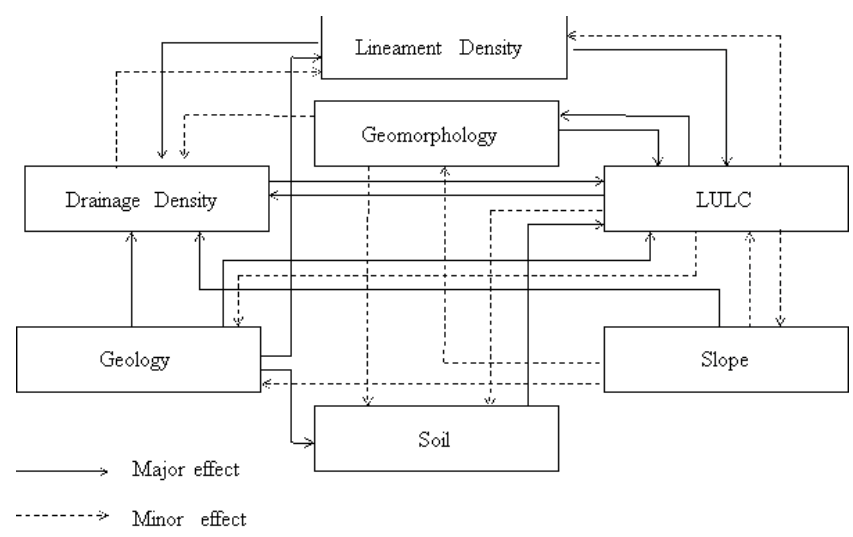

Figure 17: Interactive influences of factors concerning the recharge property.
The high recharge areas correspond to alluvial plains, areas with lineaments, which coincide with the gentle slope (0-5\%). Some parts of the blocks such as Vellakoil, Dharapuram, Sandayam, Vedasandur, Aravakurichi were identified as good groundwater recharge areas. The moderate recharge areas correspond to landuse/land cover unit of agricultural fallow land, scrub land and slope of 0-5\% which comprise of $5228.01 \mathrm{~km}^{2}$. Parts of the blocks such as Vadamadurai, Shanarpatti, Dindugal, Udumalpettai, Kundadam, Thoppampatti, etc., were subjected to moderate groundwater recharge zones. The low recharge zones mainly comprise of structural hills, landuse / land cover unit of plantation, soil classes in the hydrological soil group $\mathrm{C}$ and high degree of slope which contributes high runoff. Some parts of the blocks such as Kodaikanal, Reddiyarrchattiram, Attur, Oddanchatram, Palani, etc., were subjected to low groundwater recharge. The poor groundwater recharge zones were identified to be less than $1 \%$. Distribution of area covered by a particular potential zone class was depicted in Figure 18.

Though, there are patches of high and low moderate zones, major portion of the study area falls between moderate groundwater recharge zones. The area coverage in sq.km of the groundwater recharge zones is 
Citation: Raviraj A, Kuruppath N, Kannan B (2017) Identification of Potential Groundwater Recharge Zones Using Remote Sensing and Geographical Information System in Amaravathy Basin. J Remote Sensing \& GIS 6: 213. doi: 10.4172/2469-4134.1000213

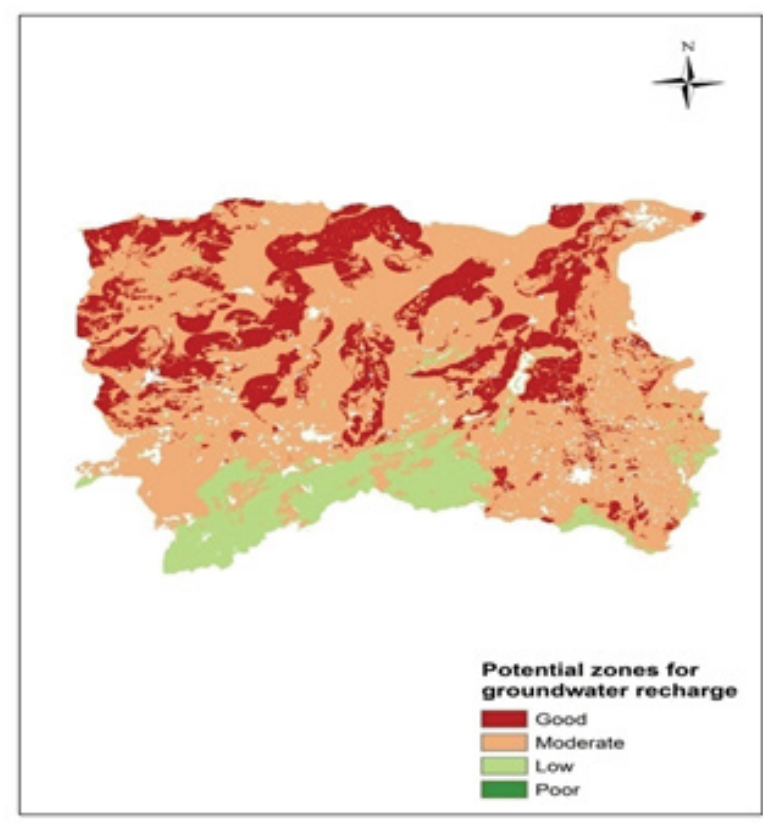

Figure 18: Distribution of Groundwater potential zone in Amaravathy basin

\begin{tabular}{|c|c|c|}
\hline S. No & Groundwater recharge zones & Area (sq.km) \\
\hline 1. & Good & 1847.208 \\
\hline 2. & Moderate & 5228.012 \\
\hline 3. & Low & 938.9997 \\
\hline 4. & Poor & 0.0162 \\
\hline
\end{tabular}

Table 5: Area of groundwater recharge zone in Amaravathy basin.

given in the Table 5 .

Artificial recharging structures are one of the effective techniques for the management of groundwater resources. Augmentation of groundwater storage is commenced either through increasing the infiltration opportunity time or creating a preferential flow to the deepseated aquifers. Structures or interventions for artificial recharge can be classified as rain water harvesting structures, on-stream interventions, injection recharge structures and groundwater dams. Rain pits, trenches, contour bunding, terracing etc reduce runoff and provide more infiltration opportunity time to rain water and thus increase deep percolation. On-stream interventions like Check Dams, Vented Cross Bars, Gabion Dams and Percolation Tanks etc. create storage in the stream for the dry season and increases infiltration opportunity time. Injection method creates an artificial preferential flow to the deep seated or confined aquifer through filter shafts and wells. This method can be combined with stream interventions and gully plugs if the bed is less permeable. Groundwater dams Block the quick subsurface lateral flow in sloping highly permeable strata and store water in head water region.

Specific recharge measures need specific site selection for the maximum effectiveness of recharge. The high recharge potential zones of the study area are key roles to construct groundwater recharge structures like recharge pits, check Dams, Gabion Dams, Percolation Tanks etc. The study area being a hard rock terrain, most effective interventions for augmenting the groundwater resource could be gully plugs, nala bunds, check dams, recharge wells etc. methods like pits, trenches, recharging of the excess runoff from hard surfaces like roads and roof tops are also possible in this area. The specific areas identified best suited for these recharge measures are Vellakoil, Dharapuram, Sandayam, Vedasandur and Aravakurichi.

\section{Proposed ground water harvesting/recharge structures}

The site suitability analysis (Figure 19) has helped in locating the suitable sites for the water harvesting structures. Based on the above classification and stream order, a map suggesting the sites for various recharge structures has been prepared (Figure 20). The hilly part of the study area with rocky outcrops and steep slopes acts as a high run off zone. The runoff washes away precious top soil from the hill slopes. Hence there is a need for proper soil moisture conservation measures and rain water harvesting and ground water recharge.

The main suggested recommendations are:

Boulder bund: These bunds are low cost small bunds across $1^{\text {st }}$ to $3^{\text {rd }}$ lower order streams. They are suitable at the upper reaches where catchments are small and stream courses have been deepened by erosion. They may be made of dry stone masonry or boulders or even brushwood. It is better to have a series of small height bunds. Since the essential function is to stabilize the gully and improve its grade by checking erosion, it is generally recommended that the foot of an upstream gully plug be at the level of the successive downstream bund.

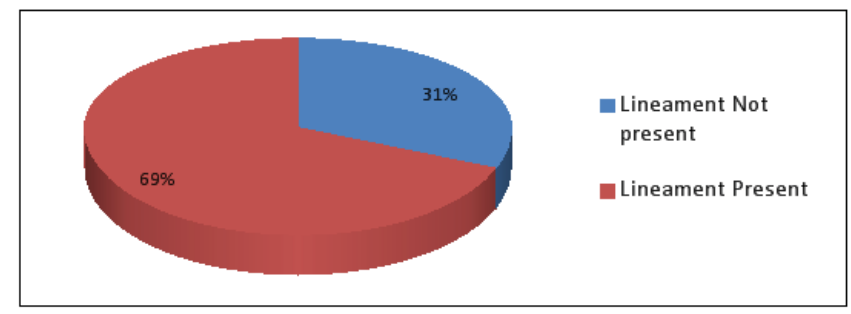

Figure 19: Groundwater recharge map of Amaravathy basin.

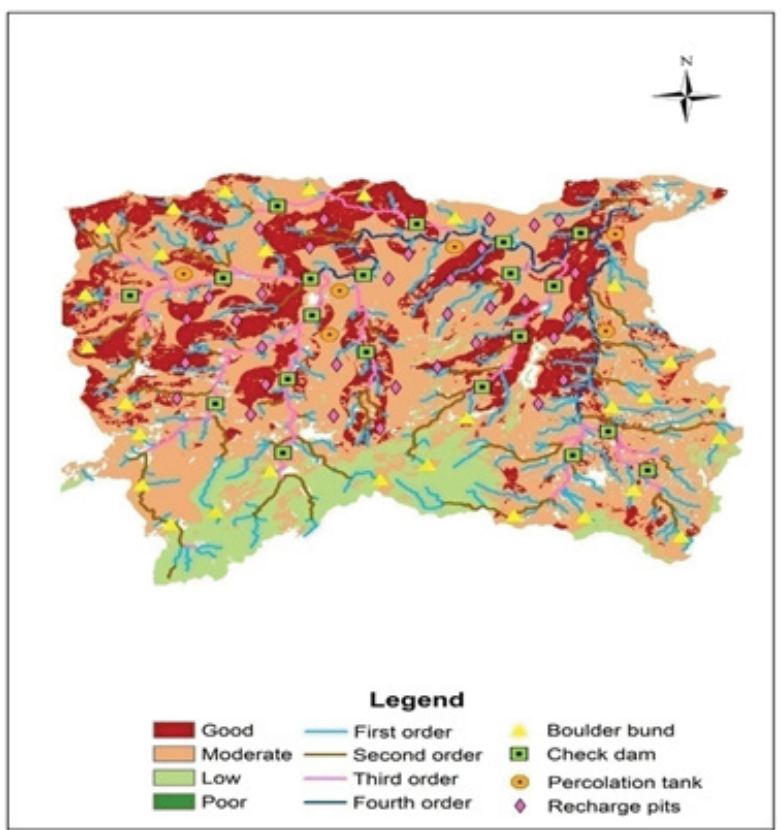

Figure 20: Proposed groundwater recharge structures in Amaravathy basin. 
Citation: Raviraj A, Kuruppath N, Kannan B (2017) Identification of Potential Groundwater Recharge Zones Using Remote Sensing and Geographical Information System in Amaravathy Basin. J Remote Sensing \& GIS 6: 213. doi: 10.4172/2469-4134.1000213

Page 10 of 10

Check dams: Check dams are engineered structures constructed across higher order $\left(>3^{\text {rd }}\right.$ order) streams having minimum average area of 25 ha. These structures are constructed for checking the stream runoff during monsoon and for storage of rain water for specific use beyond the monsoon period. Although these structures are constructed for the purpose of storage of water these may also help recharge of ground water reservoir located in the near vicinity.

Percolation/Di-siltation tanks: There are the structures built near $3^{\text {rd }}$ to $4^{\text {th }}$ order stream to impound surface run off coming from the catchments and to facilitate percolation of stored water in to the soil substrata with a view to raise groundwater level. The minimum size of the site is kept up to $40 \mathrm{ha}$. While proposing the site for percolation, it was kept in consideration the area is not presently undergoing agriculture practices. Wasteland having adequate fractures to facilitate good groundwater recharge is quite suitable for construction of percolation tanks.

Recharge pit: Recharge pits are made either by constructing an embankment across a water course or by excavating a pit or the combination of both. These structures are recommended in single crop areas for providing irrigation to limited area during critical period. The design specification of the structures will be arrived after the detailed survey at the study area. It include hydrologic hydraulic and structural engineering design.

\section{Summary}

The present study was an attempt to delineate groundwater recharge zones in Amaravathy basin, Tamilnadu. The Cartosat DEM data were used to generate layers such as drainage density, slope, etc. Land 1 use land cover, Soil, geomorphology, geology, and lineament density layers were obtained from Department of Remote sensing and GIS, TNAU.

From the results, it can be observed that high prospective zones correspond to gentle slope, soils with sandy clay loam texture, low runoff potential, high infiltration and high rainfall and low recharge zones correspond to structural hills, steep slopes, soils with clay texture, high runoff potential, low infiltration and low rainfall. The overall results demonstrate that the use of remote sensing and GIS provide potentially powerful tools to study groundwater recharge zones and suggestion of suitable recharge structures. This gives more realistic groundwater recharge map of an area which may be used for any groundwater development and management program. Various groundwater recharge structures like boulders dams, check dams, percolation tanks, recharge pits etc., were suggested in appropriate locations of Amaravathy basin.

\section{References}

1. Kavitha T, Ganesh A (2134) Geomporphometric Analysis of Amaravathy Basin Tamil Nadu. In: Water Resources Development and Management. Mittal Publications, New Delhi, India.

2. Thirunavukkarasu P, Ambujam NK (2013) Integration of remote sensing and geographic information system for delineate groundwater potential zone in the Amaravathy sub-basin, Tamil Nadu. Proceedings of the NGWC 2013 on Problems, Challenges and Management of GW in Agriculture.

3. Yeh HF, Lee $\mathrm{CH}$, Hsu KC, Chang PH (2139) GIS for the assessment of the groundwater recharge potential zone. Environmental Geology 58: 185-195.

4. Patil SG, Mohite NM (2014) Identification of groundwater recharge potential zones for a watershed using remote sensing and GIS. Int J Geomat Geosci 4: 485-498.

5. Pandiyan PS (2013) Groundwater Potential Zoning at Kancheepuram using GIS Techniques. Methodology 3: 23-32.

6. Kumar B, Kumar U (2011) Ground water recharge zonation mapping and modeling using Geomatics techniques. Int J Environ Sci 1: 1670.

7. Shaban A, Khawlie M, Abdallah C (2136) Use of remote sensing and GIS to determine recharge potential zones: the case of Occidental Lebanon. Hydrogeol J 14: 433-443.

8. Dinesh Kumar PK, Gopinath G, Seralathan P (2137) Application of remote sensing and GIS for the demarcation of groundwater potential zones of a river basin in Kerala, southwest coast of India. Int J Remote Sens 28: 5583-5601.

9. Saraf AK, Choudhury PR (1998) Integrated remote sensing and GIS for groundwater exploration and identification of artificial recharge sites. Int $\mathrm{J}$ Remote Sens 19: 1825-1841. 